\title{
Household Allocation of Time and Religiosity: Replication and Extension
}

\author{
Ronald G. Ehrenberg \\ Cornell University
}

Stephen Long and Russell Settle's (1977) empirical tests of the economic theory of religiosity presented by Corry Azzi and myself (1975) in this Journal tend to be less supportive of our theory than were our original results. As such, I welcome the opportunity to trot out some further replications and extensions that I have conducted and I leave it to the reader to judge the relative merits of the two new contributions. ${ }^{1}$

\section{Analysis of 1965 National Fertility Survey Data}

The 1965 National Fertility Survey contained data for a sample of over 5,600 females in the United States. ${ }^{2}$ Although the survey was directed primarily toward the study of reproductive behavior, it contains information on a number of dimensions of religious participation. The survey's

I am grateful to Edward Karl for his research assistance and to Dr. Fred Massarik and the Council of Jewish Federations and Welfare Funds for providing me with the data used in Section II of the paper. This paper has been drastically shortened to meet an editorial page limit and a longer more complete version is available from the author on request.

${ }^{1}$ I would be remiss, however, if I did not point out what I consider to be some glaring weaknesses in their paper. First, they utilize relatively small sample sizes, as compared to those found in both this and our previous paper, which reduces their likelihood of finding statistically significant coefficients and increases their $R^{2}$. Second, their finding of no significant impact of age on church attendance may be due to a bias induced by their omitting health status, as they acknowledge in their $\mathrm{n} .6$. Third, their restriction of the sample to males prevents them from testing the implications concerning sex differentials in religious participation, which are central to our analysis. Fourth, their wage rate ("the income contributed by the household head"), nonwage income (which includes Social Security income), and wealth (which excludes the net value of owner-occupied homes) variables are all measured with substantial error and, for the first two cases, actually depend upon the individual's time allocated to the labor market. It is thus not surprising that they tend to find insignificant coefficients here. Finally, rather than being concerned about their ability "to explain at most, only 35 percent of the variation in the frequency of church attendance with these models," they should compare explanatory powers of this magnitude to the typical $R^{2}$ found in wage equations which utilize data on individuals. Such a comparison should make them feel better about their (and our) work.

${ }^{2}$ For a detailed discussion of this survey, see Ryder and Westoff (1971).

[Journal of Political Economy, 1977, vol. 85, no. 2]

(C) 1977 by The University of Chicago. All rights reserved. 
major weakness, from our perspective, is that it failed to collect any data on actual (or potential) market wages of the surveyed individuals and their spouses.

Tables 1 and 2 present estimates, for the females and their spouses, respectively, of annual frequency of church attendance equations, which are specified as similarly as possible to those estimated in our previous paper. ${ }^{3}$ I am able to segment individuals here into nine different denominational groups because of the larger sample sizes in this survey, in contrast to the four groups used in our previous study. These estimates provide mixed support for our theory. As indicated in the bottom row of table 2, female mean attendance does exceed male mean attendance for eight of the nine denominations. Moreover, church attendance either increases with age or first decreases and then increases (as predicted by our theory) in 16 of the 18 cases, with the pattern statistically significant in 10 cases. ${ }^{4}$ In contrast, however, the female age-church attendance profile is steeper than the male profile in only four of the nine cases. Furthermore, when it is significant, increases in education increase church attendance, while total family income has no systematic effect. ${ }^{5}$ Finally, the control variables all perform in a manner similar to our previous paper.

Although our theory yields implications concerning total time devoted to religious activity, the empirical estimates presented above, in Azzi and Ehrenberg (1975), and in Long and Settle (1977) all utilize only annual frequency of church attendance as a dependent variable. Unfortunately, this variable may not be perfectly correlated with total time devoted to religious activity as it ignores such dimensions as prayer and other religious activity in the home, volunteer work for religious organizations, and membership in, or time devoted to, other church related organizations, including social clubs. Consequently, to provide further support for our theory, I also estimated equations using four additional measures of religiosity as dependent variables, for each of the seven largest denominational groups (in terms of their representation) in the sample. ${ }^{6}$

${ }^{3}$ See Azzi and Ehrenberg (1975), tables 5 and 6. The individuals' sex is included implicitly here since separate equations are estimated for males and females.

${ }^{4}$ The coefficient of age squared is included in these tables and those that follow only when an $F$-test showed that its inclusion significantly increased the explanatory power of the model.

${ }^{5}$ Rather than reflecting increased opportunity costs of time, the coefficients of the education variable may reflect the general tendency of more educated people to participate in organized activities.

${ }^{6}$ These equations included all of the exogenous variables listed in table 1 , as well as several additional variables reflecting the individual's religious background as a child. The additional religiosity measures available in the sample were a dichotomous variable $(1,0)$ measuring whether the respondent has daily religious activities in her life now, the respondent's weekly frequency of prayer at home, and a dichotomous variable indicating whether the respondent (or her husband) considers herself (himself) to be of greater than 
TABLE 1

Female Annual. Frequency of Church Attendance

\begin{tabular}{|c|c|c|c|c|c|c|c|c|c|}
\hline Variable & $\begin{array}{l}\text { Fund. } \\
\text { Protest. }\end{array}$ & Baptist & Lutheran & Episc. & Methodist & Presbyt. & Catholic & Jewish & Mormon \\
\hline $\begin{array}{l}X_{1} \ldots \ldots \\
X_{2} \ldots \ldots\end{array}$ & $\begin{array}{c}-9.945 \\
(2.3) \\
0.338 \\
(1.5)\end{array}$ & $\begin{array}{c}-1.261 \\
(0.6) \\
0.778 \\
(7.9)\end{array}$ & $\begin{array}{c}-7.072 \\
(2.4) \\
0.132 \\
(0.9)\end{array}$ & $\begin{array}{c}6.207 \\
(0.9) \\
-0.093 \\
(0.3)\end{array}$ & $\begin{array}{c}-7.042 \\
(3.5) \\
0.489 \\
(4.6)\end{array}$ & $\begin{array}{l}2.796 \\
(0.7) \\
0.499 \\
(2.6)\end{array}$ & $\begin{array}{c}-3.260 \\
(1.8) \\
-0.826 \\
(1.4) \\
0.017\end{array}$ & $\begin{array}{l}9.830 \\
(0.6) \\
0.209 \\
(0.8)\end{array}$ & $\begin{array}{c}12.532 \\
(0.9) \\
0.980 \\
(1.7)\end{array}$ \\
\hline$\ldots \ldots \ldots$ & $\ldots$ & $\ldots$ & $\cdots$ & $\cdots$ & $\cdots$ & $\cdots$ & $(2.1)$ & $\cdots$ & $\cdots$ \\
\hline 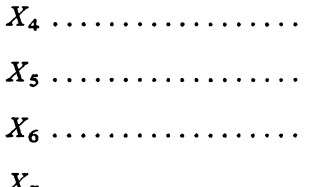 & $\begin{array}{l}1.844 \\
(2.1) \\
-0.381 \\
(0.5) \\
1.586 * \\
(2.3)\end{array}$ & $\begin{array}{l}1.670 \\
(4.3) \\
0.255 \\
(0.8) \\
0.641 * \\
(0.8) \\
-0.051 *\end{array}$ & $\begin{array}{l}0.290 \\
(0.4) \\
1.132 \\
(2.0) \\
0.249 * \\
(0.8)\end{array}$ & $\begin{array}{l}-0.089 \\
(0.6) \\
1.521 \\
(1.4) \\
4.000 * \\
(2.0) \\
-0.015+\end{array}$ & $\begin{array}{l}2.188 \\
(4.4) \\
0.937 \\
(2.4) \\
-0.168 * \\
(0.7)\end{array}$ & $\begin{array}{l}1.991 \\
(2.1) \\
0.941 \\
(1.2) \\
1.834 * \\
(1.1) \\
-0.011+\end{array}$ & $\begin{array}{l}0.739 \\
(2.2) \\
1.204 \\
(4.1) \\
0.187 * \\
(1.1)\end{array}$ & $\begin{array}{c}0.823 \\
(0.9) \\
-0.636 \\
(0.7) \\
0.033^{*} \\
(0.8)\end{array}$ & $\begin{array}{l}5.604 \\
(2.0) \\
6.451 \\
(3.5) \\
-1.500^{*} \\
(1.5)\end{array}$ \\
\hline$X_{7}$ & $\cdots$ & $\begin{array}{l}-0.051 \dagger \\
(1.3)\end{array}$ & . & $\begin{array}{l}-0.015 \dagger \\
(1.9)\end{array}$ & $\cdots$ & $\begin{array}{c}-0.011 \dagger \\
(1.7)\end{array}$ & $\cdots$ & $\ldots$ & $\cdots$ \\
\hline$X_{8} \ldots \ldots$ & $\begin{array}{c}-4.560 \\
(0.6)\end{array}$ & $\begin{array}{c}-3.279 \\
(0.8)\end{array}$ & $\begin{array}{c}-1.671 \\
(0.3)\end{array}$ & $\begin{array}{c}-18.497 \\
(1.4)\end{array}$ & $\begin{array}{l}2.865 \\
(0.7)\end{array}$ & $\begin{array}{l}5.175 \\
(0.5)\end{array}$ & $\begin{array}{c}-6.041 \\
(2.1)\end{array}$ & $\begin{array}{c}-7.877 \\
(0.9)\end{array}$ & $\begin{array}{l}4.253 \\
(1.0)\end{array}$ \\
\hline$x_{9} \ldots \ldots \ldots \ldots \ldots$ & $\begin{array}{c}-0.183 \\
(4.1)\end{array}$ & $\begin{array}{c}-0.891 \\
(0.6)\end{array}$ & $\begin{array}{c}-6.338 \\
(0.4)\end{array}$ & $\begin{array}{c}-7.457 \\
(1.2)\end{array}$ & $\begin{array}{c}-16.413 \\
(7.0)\end{array}$ & $\begin{array}{l}0.483 \\
(0.0)\end{array}$ & $\begin{array}{l}3.430 \\
(1.3)\end{array}$ & $\ldots$ & $\ldots$ \\
\hline$X_{10} \ldots \ldots \ldots \ldots \ldots$ & $\begin{array}{c}-0.388 \\
(0.2)\end{array}$ & $\begin{array}{c}-0.924 \\
(1.0)\end{array}$ & $\begin{array}{c}-4.792 \\
(2.9)\end{array}$ & $\begin{array}{c}-1.311 \\
(0.5)\end{array}$ & $\begin{array}{c}0.174 \\
(0.2)\end{array}$ & $\begin{array}{l}0.885 \\
(0.3)\end{array}$ & $\begin{array}{c}-0.667 \\
(0.9)\end{array}$ & $\begin{array}{c}-0.365 \\
(0.1)\end{array}$ & $\begin{array}{l}3.173 \\
(0.6)\end{array}$ \\
\hline$X_{11} \ldots$ & $\begin{array}{c}-0.115 \\
(1.0)\end{array}$ & $\begin{array}{l}0.025 \\
(0.5)\end{array}$ & $\begin{array}{c}-0.525 \\
(0.6)\end{array}$ & $\begin{array}{l}1.992 \\
(1.4)\end{array}$ & $\begin{array}{c}-0.205 \\
(0.3)\end{array}$ & $\begin{array}{l}1.964 \\
(1.7)\end{array}$ & $\begin{array}{l}0.881 \\
(1.8)\end{array}$ & $\begin{array}{l}3.577 \\
(1.9)\end{array}$ & $\begin{array}{l}3.460 \\
(1.5)\end{array}$ \\
\hline$X_{12} \ldots$ & $\begin{array}{l}15.144 \\
(3.8)\end{array}$ & $\begin{array}{l}16.776 \\
(8.4)\end{array}$ & $\begin{array}{l}15.312 \\
(5.0)\end{array}$ & $\begin{array}{l}11.834 \\
(2.8)\end{array}$ & $\begin{array}{l}10.727 \\
(5.2)\end{array}$ & $\begin{array}{l}15.708 \\
(4.3)\end{array}$ & $\begin{array}{l}11.108 \\
(6.9)\end{array}$ & $\begin{array}{l}9.094 \\
(1.6)\end{array}$ & $\begin{array}{l}28.764 \\
(2.9)\end{array}$ \\
\hline $\begin{array}{l}R^{2} \ldots \ldots \ldots \ldots \ldots \ldots \ldots \\
N \ldots \ldots \ldots \ldots \ldots \ldots \\
\text { Mean attendance.... }\end{array}$ & $\begin{array}{l}4^{.105} \\
55.61\end{array}$ & $\begin{array}{c}1,539.102 \\
39.75\end{array}$ & $\begin{array}{c}349^{.166} \\
30.28\end{array}$ & $\begin{array}{c}162^{.173} \\
29.09\end{array}$ & $\begin{array}{l}815^{.141} \\
31.16\end{array}$ & $\begin{array}{l}273^{.185} \\
31.74\end{array}$ & $\begin{array}{c}1,329^{.105} \\
43.22\end{array}$ & $\begin{array}{l}93.160 \\
9.56\end{array}$ & $\begin{array}{l}8.397 \\
49.62\end{array}$ \\
\hline
\end{tabular}

Source.-Data from 1965 National Fertility Survey.

Note.-Absolute $t$-statistics in parentheses; variables are defined as follows: $X_{1}, 1=$ urban, $0=$ rural; $X_{2}$, respondent's age; $X_{3}$, respondent's age squared; $X_{4}$, respondent's years of school; $X_{5}$, husband's years of school; $X_{6}$, family income in $1965 ; X_{7}$, family income squared; $X_{8}, 1=$ family income reported, $0=$ not reported; $X_{9}, 1=$ white, $0=$ nonwhite; $X_{10}$, number of children age 5 and under; $X_{11}$, number of children ages $6-18 ; X_{12}, 1=$ spouse of same religion, $0=$ spouse's religion differs.

* Choefficient has been multiplied by 1,000 .

Coefficient has been multiplied by 100,000 
TABLE 2

Male Annual Frequency of Church Attendance

\begin{tabular}{|c|c|c|c|c|c|c|c|c|c|}
\hline Variable & $\begin{array}{l}\text { Fund. } \\
\text { Protest. }\end{array}$ & Baptist & Lutheran & Episc. & Methodist & Presbyt. & Catholic & Jewish & Mormon \\
\hline$X_{1} \ldots \ldots \ldots \ldots \ldots \ldots$ & -2.343 & -6.578 & -4.321 & 16.853 & -4.246 & -2.437 & -8.444 & 10.879 & 4.836 \\
\hline$X_{2 \mathrm{H}} *$ & 0.231 & 0.339 & 0.176 & -0.202 & -0.013 & 0.690 & -0.366 & 0.517 & 1.222 \\
\hline & $(1.0)$ & $(3.9)$ & $(1.3)$ & $(0.8)$ & $\begin{array}{l}(0.1) \\
0.006\end{array}$ & $(4.0)$ & $(1.3)$ & $(1.8)$ & $(2.0)$ \\
\hline ....... & $\cdots$ & $\cdots$ & $\cdots$ & $\cdots$ & $\begin{array}{l}0.006 \\
(2.0)\end{array}$ & $\cdots$ & $\begin{array}{l}0.014 \\
(3.3)\end{array}$ & $\cdots$ & $\cdots$ \\
\hline$X_{4} \ldots$ & 0.138 & 0.435 & 0.278 & 1.350 & 0.763 & 1.001 & 1.919 & 1.498 & 3.272 \\
\hline$X_{5}$ & 0.954 & 0.880 & $\begin{array}{l}(0.4) \\
1.556\end{array}$ & 0.976 & $\begin{array}{l}(1.3) \\
2.109\end{array}$ & 3.322 & $\begin{array}{l}(3.1) \\
2.319\end{array}$ & $\begin{array}{c}(1.3) \\
-0.261\end{array}$ & $\begin{array}{l}(1.3) \\
9.292\end{array}$ \\
\hline & $(1.2)$ & (2.6) & $(2.7)$ & $(0.8)$ & $(5.4)$ & $(4.2)$ & $(4.3)$ & $(0.2)$ & $(4.3)$ \\
\hline$X_{6}$. & $\begin{array}{l}1.682 \ddagger \\
(2.4)\end{array}$ & $\begin{array}{l}0.280 \ddagger \\
(1.1)\end{array}$ & $\begin{array}{l}0.008 \ddagger \\
(0.0)\end{array}$ & $\begin{array}{l}0.485 \ddagger \\
(0.9)\end{array}$ & $\begin{array}{l}-0.610 \ddagger \\
(2.5)\end{array}$ & $\begin{array}{l}2.531 \ddagger \\
(1.6)\end{array}$ & $\begin{array}{l}0.143 \ddagger \\
(0.4)\end{array}$ & $\begin{array}{l}0.041 \ddagger \\
(0.1)\end{array}$ & $\begin{array}{c}-1.424 \ddagger \\
(1.3)\end{array}$ \\
\hline$X_{7}$ & $\cdots$ & $\ldots$ & $\cdots$ & $\cdots$ & $\ldots$ & $-0.152 \S$ & $\cdots$ & $\cdots$ & 8 \\
\hline$X_{8} \ldots$ & -1.452 & -4.985 & 2.736 & -11.043 & 4.937 & -1.453 & -4.840 & 2.64 & 26.719 \\
\hline & $\begin{array}{c}(0.2) \\
-15.524\end{array}$ & $\begin{array}{c}(1.3) \\
-2.258\end{array}$ & $\begin{array}{c}(0.5) \\
-32.995\end{array}$ & $\begin{array}{l}(0.8) \\
3.044\end{array}$ & $\begin{array}{c}(1.2) \\
-13.971\end{array}$ & $\begin{array}{l}(0.1) \\
2.665\end{array}$ & $\begin{array}{l}(0.9) \\
0.900\end{array}$ & $\begin{array}{l}(0.3) \\
11.37\end{array}$ & $\begin{array}{c}(0.9) \\
-21.674\end{array}$ \\
\hline & (3.1) & (1.3) & (2.4) & $(0.5)$ & (6.1) & $(0.4)$ & $(0.2)$ & $(0.6)$ & $(0.5)$ \\
\hline$X_{10} \ldots$ & -1.563 & -3.078 & -5.121 & -1.629 & $\begin{array}{r}-0.498 \\
\end{array}$ & 1.341 & 0.860 & -2.380 & 8.322 \\
\hline & $(0.6)$ & $(3.2)$ & $(2.9)$ & $(0.5)$ & $(0.4)$ & $(0.6)$ & $(0.6)$ & $(0.6)$ & (1.3) \\
\hline$X_{11}$ & -2.163 & 0.065 & -1.492 & 1.356 & -0.296 & -1.195 & 1.006 & 1.349 & 2.846 \\
\hline & $\begin{array}{l}(1.6) \\
37.753\end{array}$ & $(0.1)$ & $(1.7)$ & $(0.8)$ & $(0.5)$ & $(1.1)$ & $\begin{array}{l}(1.2) \\
(1.102\end{array}$ & $(0.7)$ & (1.1) \\
\hline & $\begin{array}{l}37.753 \\
(7.8)\end{array}$ & $\begin{array}{l}18.233 \\
(8.3)\end{array}$ & $\begin{array}{l}18.700 \\
(6.1)\end{array}$ & $\begin{array}{l}26.491 \\
(5.4)\end{array}$ & $\begin{array}{l}10.826 \\
(5.0)\end{array}$ & $\begin{array}{l}16.219 \\
(4.3)\end{array}$ & $\begin{array}{l}31.183 \\
(9.9)\end{array}$ & $\begin{array}{l}4.787 \\
(0.7)\end{array}$ & $\begin{array}{l}31 . .68) \\
(2.1)\end{array}$ \\
\hline \multirow{4}{*}{$\begin{array}{l}R^{2} \ldots \ldots \ldots \ldots \ldots \ldots \\
N \ldots \ldots \ldots \ldots \ldots \ldots \ldots \\
\text { Mean male attendance } \\
\text { Mean female less male } \\
\text { attendance ........... }\end{array}$} & .193 & .079 & .173 & .316 & .133 & .241 & .134 & .125 & .456 \\
\hline & 380 & 1,471 & 346 & 128 & 772 & 262 & 1,283 & 95 & 74 \\
\hline & 45.87 & 30.32 & 25.66 & 25.30 & 23.56 & 27.86 & 41.03 & 10.87 & 45.85 \\
\hline & 7.44 & 11.22 & 7.14 & 7.35 & 9.80 & 7.81 & -1.34 & 0.79 & 4.31 \\
\hline
\end{tabular}

SoURce.-Data from 1965 National Fertility Survey.

NoTE.-Absolute $t$-statistics in parentheses; variables defined as in table 1.

$X_{2} \mathrm{H}$ is husband's age.

${ }_{3} \mathrm{H}$ is husband's age squared.

$\$$ Coefficient multiplied by $1,000,000$. 
The results were quite similar to those presented above and, in particular, for three of the four measures, the data do indicate that religiosity increases with age.

\section{Analysis of the 1969 National Jereish Population Study Data}

The 1969 National Jewish Population Study was a nationwide study of approximately 7,500 families conducted by the Council of Jewish Federations and Welfare Funds. The study contains information on synagogue membership, synagogue attendance, membership in Jewish clubs and organizations, and contributions to both Jewish and non-Jewish charities. It thus allows us to test for the substitution of "time for goods" in religious participation and to test a life-cycle theory of contributions which can be generated from our model. The model's strong implications concerning life-cycle contributions are that $(a)$ even if household members face constant wage rates over their life cycle, their expenditures on goods devoted to religious activities (contributions) should increase with age, and $(b)$ if household member's wages are increasing over time, contributions may not increase with age, however, the ratio of their contributions to their church (or synagogue) attendance will increase with age. ${ }^{7}$

The most important weakness of this data set from our perspective is that no data are reported on wage rates. As a proxy, I assigned the median earnings of the experienced male civilian labor force in the husband's two-digit occupation for his wage rate. Since not all wives worked, and some worked only part-time, this procedure would contain a much larger measurement error for females. Consequently, for them I used instead average weekly hours of work, as a measure of their market participation. ${ }^{8}$

Table 3 presents estimates of equations which have as dependent variables the husband's and wife's annual frequency of synagogue attendance and number of Jewish organizations belonged to, whether the family is a synagogue member, total family contributions, total family contributions divided by husband's synagogue attendance, and the

average religious mindedness. If religious belief is influenced by church attendance, as well as vice versa, these equations all represent reduced form equations derived from a structural model and an implication of the allocation of time theory is that each of the dependent variables should increase with age (the implication that each of the dependent variables should increase with age glosses over the possibility of initially declining relationships if wage growth is sufficiently rapid-for females this is unlikely to be a problem).

${ }^{7}$ An appendix containing this model is available from the author.

${ }^{8}$ Neither proxy is very satisfactory. The male measure is actually the national male average wage in the occupation multiplied by the national male average annual hours in the occupation. The female measure is actually an endogenous variable, not a measure of the opportunity cost of time. 
TABLE 3

Analysis of National Jewish Population Study Data

\begin{tabular}{|c|c|c|c|c|c|c|c|c|}
\hline \multirow[b]{2}{*}{$\begin{array}{l}\text { INDEPENDENT } \\
\text { VARIABLE }\end{array}$} & \multicolumn{8}{|c|}{ Dependent Variable } \\
\hline & $\begin{array}{l}Y_{1} \\
(1)\end{array}$ & $\begin{array}{l}Y_{2} \\
(2)\end{array}$ & $\begin{array}{l}Y_{3} \\
(3)\end{array}$ & $\begin{array}{l}Y_{4} \\
(4)\end{array}$ & $\begin{array}{l}Y_{5} \\
(5)\end{array}$ & $\begin{array}{l}Y_{6} \\
(6)\end{array}$ & $\begin{array}{l}Y_{7} \\
(7)\end{array}$ & $\begin{array}{l}Y_{8} \\
(8)\end{array}$ \\
\hline$X_{1} \ldots$ & $\begin{array}{c}-1.646 \\
(2.1)\end{array}$ & $\begin{array}{l}0.017 \\
(5.6)\end{array}$ & $\ldots$ & $\ldots$ & $\begin{array}{l}0.005 \\
(6.2)\end{array}$ & $\begin{array}{r}-54.95 \\
(2.1)\end{array}$ & $\begin{array}{l}3.509 \\
(2.0)\end{array}$ & $\begin{array}{c}-0.002 \\
(3.9)\end{array}$ \\
\hline ......... & $\begin{array}{l}0.017 \\
(2.1)\end{array}$ & $\ldots$ & $\cdots$ & $\cdots$ & $\ldots$ & $\begin{array}{r}0.75 \\
(3.0)\end{array}$ & $\ldots$ & $\ldots$ \\
\hline$X_{3}$ & $\begin{array}{l}13.706 \\
(4.4)\end{array}$ & $\begin{array}{c}0.240 \\
(3.7)\end{array}$ & $\begin{array}{l}7.823 \\
(6.8)\end{array}$ & $\begin{array}{l}0.293 \\
(4.1)\end{array}$ & $\begin{array}{c}0.130 \\
(7.1)\end{array}$ & $\begin{array}{c}34.63 \\
(0.3)\end{array}$ & $\begin{array}{c}-124.140 \\
(3.4)\end{array}$ & $\begin{array}{c}0.034 \\
(4.2)\end{array}$ \\
\hline$X_{4}$. & $\begin{array}{l}17.954 \\
(5.2)\end{array}$ & $\begin{array}{l}0.133 \\
(1.8)\end{array}$ & $\begin{array}{l}3.750 \\
(3.0)\end{array}$ & $\begin{array}{c}0.112 \\
(1.4)\end{array}$ & $\begin{array}{l}0.053 \\
(2.7)\end{array}$ & $\begin{array}{r}-26.98 \\
(0.2)\end{array}$ & $\begin{array}{c}-15.036 \\
(0.4)\end{array}$ & $\begin{array}{l}0.011 \\
(1.2)\end{array}$ \\
\hline$X_{5}$. & $\begin{array}{l}19.210 \\
(0.3)\end{array}$ & 0.036 & 0.532 & $\begin{array}{l}-0.202 \\
(1.4)\end{array}$ & -0.046 & $\begin{array}{r}-66.34 \\
(0.3)\end{array}$ & -21.316 & 0.029 \\
\hline$X_{6}$ & 12.950 & -0.395 & -2.882 & -0.641 & -0.181 & -35.40 & -20.694 & 0.036 \\
\hline$X_{7}$ & 0.147 & $\begin{array}{l}(3.4) \\
0.031\end{array}$ & $\begin{array}{l}(2.2) \\
\ldots\end{array}$ & $\begin{array}{r}(8.0) \\
\ldots .\end{array}$ & $\begin{array}{l}(8.9) \\
0.009\end{array}$ & $\begin{array}{r}(0.3) \\
-7.57\end{array}$ & $\begin{array}{c}(0.5) \\
-0.793\end{array}$ & $\begin{array}{l}(3.9) \\
0.000\end{array}$ \\
\hline$X_{8} \ldots$ & $\begin{array}{c}(0.4) \\
-0.013\end{array}$ & $\begin{array}{l}(3.7) \\
0.003 *\end{array}$ & - & $\ldots$ & $\begin{array}{l}(4.0) \\
0.001 *\end{array}$ & $\begin{array}{c}(0.6) \\
0.02\end{array}$ & $\begin{array}{c}(0.2) \\
-0.001\end{array}$ & $\begin{array}{l}(0.0) \\
0.005^{*}\end{array}$ \\
\hline & $(2.6)$ & $(3.0)$ & & & (4.7) & $(1.0)$ & $(0.2)$ & $(4.7)$ \\
\hline$X_{9}$. & $\begin{array}{l}-0.008^{*} \\
(1.0)\end{array}$ & $\begin{array}{l}0.002 * \\
(11.5)\end{array}$ & $\begin{array}{l}-0.003 * \\
(1.1)\end{array}$ & $\begin{array}{l}0.002^{*} \\
(12.9)\end{array}$ & $\begin{array}{l}0.003^{*} \\
(5.8)\end{array}$ & $\begin{array}{c}0.084 \\
(32.0)\end{array}$ & $\begin{array}{l}0.017 \\
(18.2)\end{array}$ & $\begin{array}{c}-0.002 * \\
(9.0)\end{array}$ \\
\hline$X_{10} \ldots$ & 28.902 & $\begin{array}{l}0.263 \\
(2.2)\end{array}$ & $\ldots$ & $\ldots$ & $\begin{array}{l}0.095 \\
(2.8)\end{array}$ & $\begin{array}{l}0.010 \\
(2.8)\end{array}$ & $\begin{array}{r}-83.18 \\
(1.2)\end{array}$ & 0.064 \\
\hline$X_{11} \ldots$ & 3.406 & 0.057 & 10.468 & -0.045 & 0.005 & 61.07 & -9.320 & 0.002 \\
\hline & $(1.2)$ & $(1.0)$ & $(0.9)$ & $(0.7)$ & $(0.3)$ & $(0.7)$ & $(0.3)$ & $(0.3)$ \\
\hline$X_{12} \ldots$ & 2.737 & -0.003 & 17.850 & -0.024 & 0.080 & -41.97 & -47.700 & 0.012 \\
\hline$X_{13} \ldots$ & $\begin{array}{l}(1.9) \\
3.286\end{array}$ & $\begin{array}{l}(1.0) \\
-0.056\end{array}$ & $\begin{array}{l}(3.4) \\
0.031\end{array}$ & $\begin{array}{c}(0.8) \\
-0.016\end{array}$ & $\begin{array}{l}(10.1) \\
0.007\end{array}$ & $\begin{array}{l}(0.9) \\
51.21\end{array}$ & $\begin{array}{l}(3.0) \\
5.233\end{array}$ & $\begin{array}{l}(3.3) \\
0.001\end{array}$ \\
\hline & (1.8) & $(1.4)$ & $(0.4)$ & $(0.4)$ & $(0.7)$ & $(0.8)$ & $(0.2)$ & $(0.2)$ \\
\hline
\end{tabular}




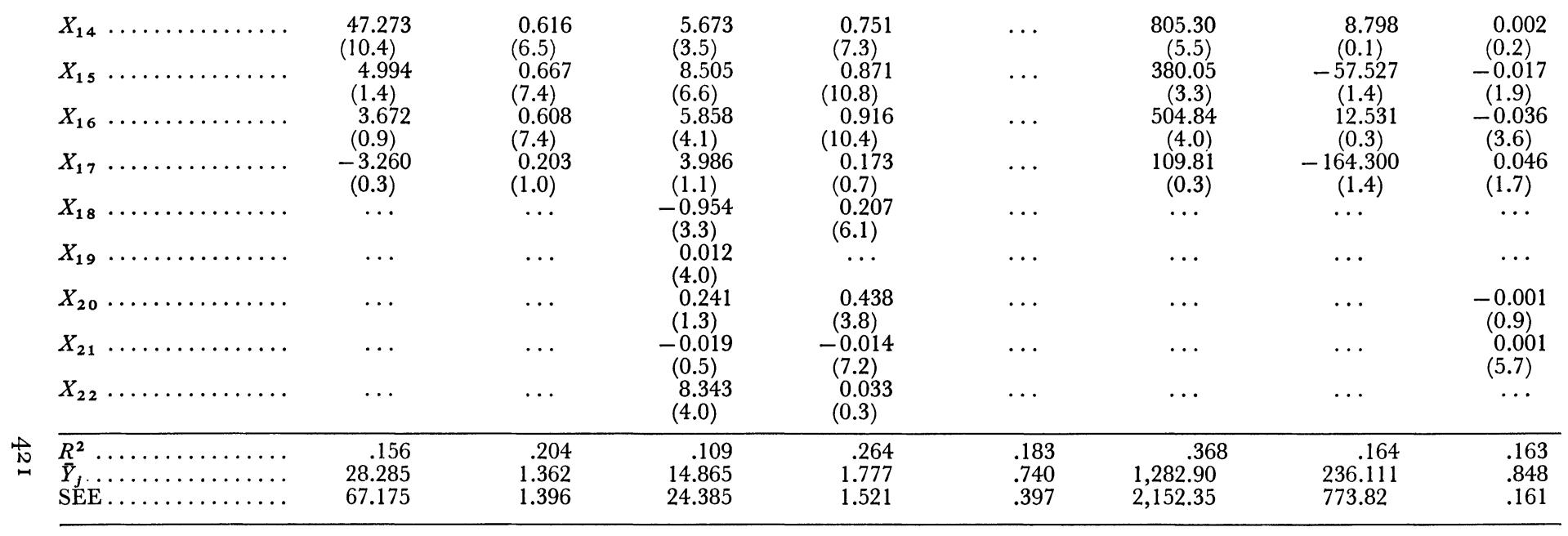

Source.-Data from 1969 National Jewish Population Study.

NotE. -Absolute $t$-statistics in parentheses; $N=2,427$ for all equations; independent variables are defined as follows: $X_{1}$, husband's age ( $X_{18}$ for wife); $X_{2}$, husband's age squared $\left(X_{19}\right.$ for wife $) ; X_{3}, 1=$ household observes the sabbath, $0=$ other; $X_{4}, 1=$ household keeps a kosher home, $0=$ other; $X_{5}, 1=$ household moved to city within the past 3 years, $0=$ other; $X_{6}, 1=$ household lives in New York City, $0=$ other; $X_{7}$, husband's years of school $\left(X_{20}\right.$ for wife); $X_{8}$, median earnings of experienced male civilian labor force in 1969 in husband's two-digit occupation (in thousands); $X_{9}$, total family income in $1969 ; X_{10}$, fraction of the following six questions which the husband answered yes to ( $X_{22}$ for wife)- $(1)$ My father was active in Jewish life when 1 was a child. (2) My mother was active in Jewish life when 1 was a child. (3) $I$ believe in the Jewish Religion. (4) 1 believe in one God. (5) 1 pray. (6) 1 know religious teachings; $X_{11}$, number of children age 5 and under in the household; $X_{12}$, number of children ages $6-18$ in the household; $X_{13}$, number of other adults in the household; $X_{14}, 1=$ household is a member of an orthodox synagogue, $0=$ other; $X_{15}$, $1=$ household is a member of a conservative synagogue,

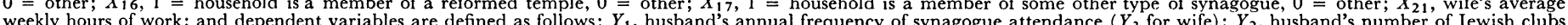
belonged to $\left(Y_{4}\right.$ for wife). $Y_{5}, 1=$ synagogue member, $0=$ other; $Y_{6}$, total family contributions in 1969 ; $Y_{7}$, total family contributions/husband's synagogue attendance; $Y_{8}$ husband's attendance/(husband's attendance plus wife's attendance).

* Coefficient has been multiplied by 100 . 
husband's frequency of attendance divided by the total of his and his wife's attendance. These equations were estimated utilizing a sample of 2,427 families in which both spouses were present, both reported positive synagogue attendance, and the family reported positive contributions in $1969 .^{9}$

The estimates strongly support his life-cycle implications of the theory. Both male and female life-cycle synagogue attendance profiles are $\mathrm{U}$-shaped, first declining and then increasing with age. Moreover, the slope of the female profile is always steeper than the slope of the male profile, hence the ratio of female to male attendance increases with age (cols. 1, 3, 8). Similarly, the probability of being a synagogue member increases with age, as does the number of Jewish clubs to which both spouses belong (cols. 2, 4, 5). In the latter case, again in strong confirmation of our theory, the rate of increase is more rapid for females than males. Finally, the data indicate (col. 7), as the theory predicts, that the ratio of contributions to synagogue attendance increases with age. ${ }^{10}$

Focusing next on the wage rate proxies, we see that increases in the husband's wage decreases his synagogue attendance (col. 1) and decreases the ratio of his attendance to the total of his and his spouse's attendance (col. 8) as expected. Similarly, increases in the wife's weekly hours of work increase the ratio of the husband's attendance to the combined total of both their synagogue attendances. Together, this provides strong evidence that relative wages matter in the determination of the intrafamily allocation of time to religious activities. Finally, observe that increases in total family income lead to increases in both spouses' participation in clubs, the probability of the family being a synagogue member, the level of contributions, and the ratio of contributions to attendance. All of these impacts are consistent with the allocation of time model.

In the main, then, predictions of the model concerning the life-cycle allocation of market goods and household time to religious activity and the

\footnotetext{
${ }^{9}$ As cols. 1 and 3 indicate, mean female attendance is less than mean male attendance. This "contradiction" of our theory is due to institutional rules which give males the primary role in the synagogue service. Note, however, that the ratio of male attendance to total family attendance (col. 8) declines as we move from the traditional orthodox denomination $\left(X_{14}\right)$ to the progressively more liberal conservative $\left(X_{15}\right)$ and reformed denominations $\left(X_{16}\right)$. Moreover, mean female participation in Jewish clubs does exceed mean male participation (cols. 2 and 4 ).

${ }^{10}$ Substitution of contributions directed to Jewish charities for total contributions yielded results virtually identical to those reported in cols. 6 and 7. The results in col. 6 indicate that the age-contribution profile is $U$-shaped, increasing from roughly age 37 on. As I indicated in the text, with increasing wage rates over the life cycle, no strong implications about the shape of this profile come from the model. Other investigators have found contributions increasing with age, however (e.g., see Roistacher and Morgan 1974).
} 
intrafamily allocation of time, at a point in time, have been verified. ${ }^{11}$ Consequently, although the evidence is not totally unambiguous, the estimates discussed here do lend further support to the view that religious participation, like other nonmarket activities, can be usefully analyzed in a household allocation of time framework.

\section{References}

Azzi, C., and Ehrenberg, R. "Household Allocation of Time and Church Attendance." J.P.E. 83, no. 1 (February 1975): 27-56.

Long, S., and Settle, R. "Household Allocation of Time and Church Attendance: Some Additional Evidence." J.P.E. 85, no. 2 (April 1977): 409-13.

Roistacher, E., and Morgan J. Charitable Giving, Property Taxes and Itemization on Federal Tax Returns. Ann Arbor: Inst. Soc. Res., Univ. Michigan, 1974.

Ryder, N., and Westoff, C. Reproduction in the United States 1965. Princeton, N.J.: Princeton Univ. Press, 1971.

${ }^{11}$ Several individuals have suggested to me that the cross-sectional relationship between age and religious participation may reflect a cohort or generational effect, rather than a life-cycle effect. However, neither they nor anyone else has suggested that the strong prediction of the model that females' age-religious participation profiles will be steeper than males' profiles, which often appears verified by the cross-section data, could be explained with reference to cohort effects. 